\title{
Kearifan Lokal Masyarakat Desa Seloto dalam Pengelolaan Sumberdaya Alam Di Danau Lebo
}

\author{
Iwan Doddy Dharmawibawa \\ Dosen Pendidikan Biologi IKIP Mataram \\ iwandoddydharmawibawa@ikipmataram.ac.id
}

\begin{abstract}
Abstrak: Kearifan lokal merupakan suatu bentuk kearifan lingkungan yang ada dalam kehidupan bermasyarakat disuatu tempat dan merupakan warisan nenek moyang dalam tata nilai kehidupan yang menyatu dalam bentuk religi, budaya,dan adat-istiadat. Pengabdian masyarakat ini bertujuan untuk menganalisis kearifan local masyarakat Desa Seloto dalam pengelolaan sumberdayaalam d iDanau Lebo. Teknik pengumpulan data dilakukan dengan metode wawancara, dokumentasi, dan Observasi. Data dianalisis menggunakan metode deskriptif. Berdasarkan hasil pengamatan yang dilakukan di Desa Seloto ditemukan kearifan local yaitu budaya mali atau pamali, budaya mali tersebut diantaranya larangan menangkap ikan malam juam'at (No Roa Tu Bau Empa Petang Jemat), larangan menangkap ikan kecil (Bau Anu Rango Lepas Anu Ode) dan di bulan purnama (Bulan Buntar). Sementara di desa Air Suning dan Meraran memiliki kearifan local berupa kepercayaan kepada mahluk gaib penguasan perairan (Dea Bide).
\end{abstract}

\section{Katakunci: Kearifan lokal, sumberdaya alam}

\section{PENDAHULUAN}

Kearifan lokal merupakan budaya yang dimiliki oleh masyarakat tertentu ditempat tertentu yang dianggap mampu bertahan dalam menghadapi arus globalisasi, karena kearifan local tersebut mengandung nilai-nilai yang dapat dijadikan sebagai sarana pembangunan karakter bangsa. Yunus Rasid (2014), menyebutkan bahwa kearifan lokal merupakan tata nilai atau perilaku hidup masyarakat lokal dalam berinteraksi dengan lingkungan tempat hidupnya secara arif. Makadari itu kearifan local tidaklah sama pada tempat dan waktu yang berbeda dan suku yang berbeda. Sementara itu Keraf (2002) dalam Suhartini (2009), menegaskan bahwa kearifan lokal adalah semua bentuk pengetahuan, keyakinan, pemahaman atau wawasan serta adat kebiasaan atau etika yang menuntun perilaku manusia dalam kehidupan di dalam komunitas ekologis. Semua bentuk kearifan lokal ini dihayati, dipraktekkan, diajarkan dan diwariskan dari generasi ke generasi sekaligus membentuk pola perilaku manusia terhadap sesame manusia.

Sumber daya alam merupakan kekayaan yang dimiliki oleh alam yang harus di jaga kelestarian demi kelangsungan hidup umat manusia. Beberapa kebiasaan masayarakat dalam pengelolaan sumberdaya alam antara lain: menggunakan pupuk dan pestisida sesuai kebutuhan, membatasi penggunaan sumberdaya alam, tidak membuang zat pencemar dan racun kesaluran air, membuat terasering atau sengkedan pada lahan miring.

Danau Lebo atau danau Rawa Taliwang memiliki sumberdaya alam yang melimpah yang dimanfaatkan oleh masyarakat sekitar. Danau Rawa Taliwang terdapat di Kecamatan Taliwang dan Kecamatan Seteluk, Kabupaten Sumbawa Barat, Propinsi Nusa Tenggara Barat. Lokasinya tak jauh dari kota Taliwang, ibu kota Kabupaten Sumbawa Barat. Danau Rawa Taliwang berada pada ketinggian 7,5 $\mathrm{m}$ diatas permukaan laut dengan keadalaman perairan antara $0,70 \mathrm{~m}$ sampai $3,5 \mathrm{~m}$ dengan luas 1.406ha dan merupakan daratan basah alami terluas di Provinsi Nusa Tenggara Barat.

\section{POTENSI DAERAH}

Desa Seloto merupakan sebuah desa yang yang termasuk dalam wilayah Kecamatan Taliwang Kabupaten Sumbawa Barat. Luas wilayah Desa Seloto adalah 1100 Ha yang terdiri dari 3 dusun yaitu Dusun Brang Bulu, Dusun Brang Pandang, dan Dusun Lenang Lateh. Secara goeografis, Desa Seloto terletak tidak jauh dari Danau Lebo tepatnya disebelah timur Danau lebo, dengan batas-batas wilayah sebagai berikut: sebelah Utara berbatasan dengan Kecamatan Alas 
Barat, sebelah Timur berbatasan dengan Kecamatan Brang Rea, sebelah selatan berbatsan dengan Kelurahan Sampir Kecamatan Taliwang dan sebelah Barat berbatsan dengan Kecamatan Seteluk. Masyarakat Desa Seloto hidup sebagai petani dan nelayan dengan memanfaatkan Sumber daya alam yang ada di Danau Lebo dengan cara menangkap ikan yang ada di danau untuk dikonsumsi sehari-hari dan dijual sebagai penambah penghasilan. Dalam mengelola sumber daya alam yang ada di danau supaya tetap terjaga dengan baik, masayarakat Desa Seloto memiliki aturan atau awig-awig yang berlaku ketika masyarakat Desa Seloto akan memanfaatkan sumber daya alam yang ada didanau tersebut. Adapun awiq-awiq tersebut dalam Bahasa daerah disebut dengan NoRoaTuBau Empa Petang Jemat, Mali, Bauanurangokelepa sanuode, dan bulan buntar.

Pengabdian masyarakat ini mengkaji kearifan lokal yang dipelihara di Desa Seloto untuk menjaga sumber daya alam yang ada di danau tetap lestari sehingga dapat dimanfaatkan oleh generasi penerus Desa Seloto. Berdasarkan hal diatas maka keberadaan kearifan local perlu dilestarikan.

\section{TINJAUAN PUSTAKA}

\section{1) Tinjaun Tentang kearifan Lokal}

Kearifan setempat (lokal wisdom) yang dapat dipahami sebagai gagasan-gagasan local yang bersifat bijaksana, penuhkearifan, memiliki nilai moral yang tertanam dan diikuti oleh warga masyarakatnya. Dalam konsep antropologi, kearifan local dikenal pula sebagai pengetahuan setempat (indigenous or local knowledge), atau kecerdasan setempat (local genius), yang menjadi dasar identitas kebudayaan. Kearifan lokal juga disebut sebagai perwujudan atas tradisi masyarakat setempat berupa aktivitas sekitar daur kehidupan, lingkungan alam, dan lingkungan sosial yang kemudian diinterperetasi sebagai pengetahuan lokal. Yunus Rasid (2014), kearifan lokal merupakan tata nilai atau perilaku hidup masyarakat lokal dalam berinteraksi dengan lingkungan tempatnya hidup secara arif. Makadari itu kearifan local tidaklah sama pada tempat dan waktu yang berbeda dan suku yang berbeda.

Sementara itu Keraf (2002) dalam
Suhartini (2009), menegaskan bahwa kearifan lokal adalah semua bentuk pengetahuan, keyakinan, pemahaman atau wawasan serta adat kebiasaan atau etika yang menuntun perilaku manusia dalam kehidupan di dalam komunitas ekologis. Semua bentuk kearifan lokal ini dihayati, dipraktekkan, diajarkan dan diwariskan dari generasi ke generasi sekaligus membentuk pola perilaku manusia terhadap sesama manusia, alam maupun gaib.

Sartini (2006) dalam Taprianto (2013) menyatakan bahwa bahwa fungsi kearifan lokal adalah sebagai berikut:

1. Berfungsi sebagai konservasi dan pelestarian sumber daya alam.

2. Berfungsi untuk pengembangan sumber daya manusia

3. Berfungsi untuk pengembangan kebudayaan dan ilmu pengetahuan

4. Berfungsi sebagai petuah kepercayaan satra dan pantangan

5. Bermakna sosial misalnya upacara intergrasi komunal/kerabat

6. Bermakna sosial, misalnya pada upacara daur pertanian

7. Bermakna etika dan moral

2) Tinjauan Tentang Sumber Daya Alam

Sumber daya alam adalah suatu bentuk bahan atau energi yang diperoleh dari lingkungan fisik yang dapat digunakan untuk memenuhi kebutuhan manusia. (Agoes Soegianto, 2010). Undang-Undang No.32 Tahun 2009 juga menjelaskan tentang pengertian sumber daya alam yaitu unsure lingkungan hidup yang terdiri atas sumber daya hayati dan non hayati yang secara keseluruhan membentuk ekosistem.

Cara pandang manusia terhadap sumber daya alam sangat mempengaruhi kesadaran lingkungan dan cara mengelola sumber daya alam yang dilakukannya. Kesadaran lingkungan merupakan suatu proses mental yang membentuk pengertian tertentu atas sumber daya alam dan lingkungan sekitar kita.

1. Klasifikasi Sumber DayaAlam

Ada berbagai cara mengklasifikasi sumber daya alam. Diantaranya adalah dengan berdasar pada bagaimana sumber daya alam tersebut dapat terbarukan dan siapa yang mendapatkan manfaat dari sumber daya alam tersebut. 
1) Prepartual resources: merupakan sumber daya yang tersedia secara terus-menerus contohnya adalah matahari.

2) Renewable orflow resources: merupakan sumber daya yang terbarukan misalnya hutan, air, dan sumber daya perikanan.

3) Nonrenewable orstock resources: merupakan sumber daya yang tidak terbarukan misalnya sumber daya mineral.

4) Potential resources: sumber daya masa depan.

Adalah sumberdaya yang tidak dapat digantikan oleh proses alam atau laju pergantiannya lebih rendah dari laju pemanfaatannya

2. Konservasi sumber daya alam.

Salah satu pemahaman tentang konservasi sumber daya alam adalah penggunaan sumber daya alam untuk kebaikan secara optimal, dalam jumlah terbanyak dan utuk jangka waktu yang paling lama, konservasi sumber daya alam diartikan sebagai pengurangan atau peniadaan penggunaan karena lebih mengutamakan bentuk penggunaan lain dalam hal sumber daya memiliki penggunaan bermacam macam (multiple use resources).

Undang-undang No. 32 Tahun 2009 juga menjelaskan tentang konservasi sumber daya alam yaitu pengelolaaan sumber daya alam untuk menjamin pemanfaatannya secara bijaksana serta berkesinambungan ketersediaanya dengan tetap memelihara dan meningkatkan kualitas nilai serta keanekaragamannya.

\section{METODE PELAKSANAAN \\ Instrumen Pengamatan}

Instrumen yang digunakan dalam pengabdian masyarakat ini adalah

1. Pengamat sebagai instrument (human instrument)

Artinya peneliti sendiri yang berfungsi menentukan fokus penelitian, memilih informan sebagai sumber data, melakukan pengumpulan data, analisis data,dan membuat kesimpulan atas temuannya.

2. Wawancara

Merupakan kegiatan tanyajawab dengan narasumber untuk mendapatkan data mengenai fokus penelitian. Dalam melakukan wawancara menggunakan instrument berupa:

a) Buku catatan, yang digunakan untuk mencatat hasil wawancara, b) Tape recorder yang digunakan untuk merekam hasil wawancara masyarakat.

3. Dokumentasi

Merupakan kegiatan mengambil gambar atau potret ketika saat sedang melakukan pengamatan. Dalam melakukan kegiatan dokumentasi menggunakan instrument diantaranya:

a. Kamera yang digunakan sebagai alat dokumentasi

b. Handycam yan gdigunakan untuk membuat video dokumentasi

\section{Teknik Pengumpulan Data}

Teknik pengumpulan data dalam penelitian ini dilakukan dengan:

1. Teknik wawancara atau interview yaitu suatu teknik pengumpulan data dengan mewawancarai narasumber atau informan untuk mendapatkan data-data mengenai kearifan lokal

2. Dokumentasi yaitu dengan mendokumentasikan data-data, kegiatan dan lingkungan sekitar yang biasa berbentuk gambar dan tulisan yang merupakan pelengkap dari metode wawancara.

\section{Teknik Analisa Data}

1. Wawancara Yaitu dengan mendeskripsikan data yang telah didapat dari proses pengumpulan data dengan teknik wawancara

2. Dokumentasi yaitu dengan mendeskripsikan data yang telah didapat berdasar hasil dokumentasi yakni berupa gambar gambar dan dokumen lainnya.

\section{HASIL PENGAMATAN \\ Hasil Pengamatan}

Wawancara dengan narasumber dari beberapa wilayah di sekitar Danau Lebo termasuk Desa Seloto, Seran dan Air Suning.

1. Ustadz M Suud selaku tokoh agama sekaligus adat Desa Seloto

2. Bapak Amrin selaku nelayan Desa Seloto

3. Bapak Rosadi selaku nelayan DesaSeloto

4. Bapak Aminullah selaku nelayan Desa Meraran

5. Bapak Jamaluddin selaku nelayan Desa Seran

\section{Pentingnya Kearifan Lokal}

Masayarakat Desa Seloto yang 
memanfaatkan Danau Lebo sebagai sumber mata pencahariannya sangat memahami betul akan pentingnya kearifan lokal, karena kearifan lokal merupakan komponen yang sangat penting dalam pengelolaan sumber daya alam dan merupakan perwujudan pengetahuan atau ide, norma adat yang diwariskan secara turun-temurun dan menjadi pedoman dalam pengelolaan sumber daya alam, setelah dilakukannya pegamatan dan wawancara terhadap beberapa nelayan Desa Seloto ditemukannya kearifan lokal dan mitos-mitos yang masih berlaku dan diterapkan di Danau Lebo. Kearifan lokal yang masih diterapkan di Danau Lebo hingga saat ini adalah Mali atau dalam Bahasa Indonesianya pamali, Untuk mengetahui lebih lanjut mengenai budaya mali dalam Pengelolaan sumber daya alam maka marilah kita lihat pada tabel di bawah ini.

Tabel Budaya Mali dalam Pengelolaan sumber Daya Alam.

\begin{tabular}{|c|l|l|}
\hline No & $\begin{array}{l}\text { Budaya mali dalam pengelolaan } \\
\text { sumber daya alam }\end{array}$ & Terjemahan dalam Bahasa Indonesia \\
\hline 1 & $\begin{array}{l}\text { No bau tub au empapetang } \\
\text { jemat. }\end{array}$ & $\begin{array}{l}\text { Tidak boleh keluar maupun } \\
\text { menangkap ikan pada malam jum'at }\end{array}$ \\
\hline 2 & Bau anu rango, lepasanu odena. & $\begin{array}{l}\text { Tangkap ikan yang besar, Lepas } \\
\text { yang kecil. }\end{array}$ \\
\hline 3 & Bulan buntar & Bulan purnama. \\
\hline
\end{tabular}

Tabel Bentuk Kearifan Lokal yang diterapkan di Danau Lebo

\begin{tabular}{|l|l|}
\hline Kearifan lokal & Budaya Pamali \\
\hline Nilai & $\begin{array}{l}\text { Kepercayaan terhadap kekuatan gaib dan } \\
\text { supranatural. }\end{array}$ \\
\hline Norma & $\begin{array}{l}\text { Pelestarian sumber daya alam } \\
\text { Pelarangan menangkap ikan kecil } \\
\text { Pelarangan menangkap ikan malam Jum'at }\end{array}$ \\
\hline Aktor & Seluruh masyarakat Desa Seloto \\
\hline & $\begin{array}{l}\text { Seluruh pelanggaran terhadap mali (pamali) dapat } \\
\text { menyebabkan terjadinya musibah bukan saja kepada } \\
\text { pelanggar tapi juga mengenai seluruh masyarakat desa }\end{array}$ \\
\hline
\end{tabular}

\section{Perilaku Manusia}

Keberadaan kearifan lokal dalam pengelolaan Sember daya alam di Danau Lebo menjadi suatu aturan yang harus dipatuhi dan menjadi acauan masayarakat dalam mengelola Danau Lebo. Masyarakat desa Seloto kebanyakan menangkap ikan di Danau Lebo untuk memenuhi kebutuhan sehari-hari mereka. Berdasarkan hasil wawancara dengan bapak Rosadi dan Amrin menjelaskan bahwa Masyarakat Desa Seloto yang menangkap ikan di Danau lebo terikat oleh budaya mali diantaranya: Masyarakat tidak diperbolehkan menangkap ikan pada hari dan malam Jum'at dan masyarakat juga tidak diperbolehkan menangkap ikan pada saat bulan purnama selain itu terdapat juga kebiasaan lainnya yang harus dilakukan oleh masyarakat yaitu masyarakat hanya menangkap ikan besar dan tidak menangkap ikan kecil. Kebiasaan masyarakat Desa Seloto dalam menangkap ikan yakni masih menggunakan alat alat tradisional seperti jaring, rageng (tombak), panah, dan kodong dan tidak menggunakan alat berbahaya seperti racun bom dan sebagainya karena dapat merusak lingkungan.

\section{Tantangan Terhadap Kearifan Lokal}

Berdasarkan hasil wawancara dengan beberapa orang nara sumber bahwa masyarakat memiliki hambatan dan tantangan dalam melestarikan kearifan lokal diantaranya jumlah penduduk yang terus meningkat, sehingga kebutuhan akan sumber daya alam begitu besar, adanya teknologi modern dan budaya baru masuk yang dibawa oleh pendatang baru, sehingga dikawatirkan akan terpengaruh dengan teknologi dan budaya baru dan melupakan kearifan lokal yang ada.

\section{Upaya Masyarakat dan Pemerintah Dalam Pelestarian Sumber Daya Alam}

Upaya masyarakat Desa Seloto dalam menjaga kelestarian sumber daya alam khususnya di Danau Lebo yakni dengan adanya awiq-awiq atau kearifan lokal masyarakat, salah satunya yakni budaya mali atau pamali yang di terapkan masyarakat dalam pengelolaan sumber daya alam. Budaya mali itu sendiri memiliki tiga aturan yang harus dipatuhi oleh masyarakat desa diantaranya: larangan menangkap ikan pada hari dan malam Jum'at, larangan menangkap ikan saat bulan purnama dan larangan menangkap ikan-ikan kecil di Danau Lebo

Pemerintah desa juga mengatur tentang pelestarian sumber daya alam dalam peraturan desa tentang pelestarian lingkungan hidup yaitu pada pasal 5 yang berbunyi setiap orang berhak untuk berperan dalam perlindungan dan pengelolaan lingkungan hidup sesuai dengan peraturan perundangundangan yang berlaku,dan pada pasal 6 berbunyi setiap orang berkewajiban memelihara fungsi lingkungan hidup serta mengendalikan pencemaran dan kerusakan lingkungan hidup

Upaya pemerintah dalam dalam menjaga dan melestarikan sumberdaya alam ini tertuang dalam UURINO 32 Tahun 2009 
pasal 67 yang berbunyi setiap orang berkewajiban memelihara fungsi lingkungan hidup serta mengendalikan pencemaran dan kerusakan lingkungan hidup

\section{PEMBAHASAN}

Berdasarkan hasil wawancara dan diskusi dengan tokoh agama Desa bahwa Masyarakat Desa Seloto memiliki kearifan lokal yang sudah diwariskan oleh leluhur mereka. Kearifan lokal masih tetap dijalankan sampai saat ini karena sifatnya amanah sehingga harus dilaksanakan sesuai dengan aturan main yang ada di Desa Seloto. Bentuk kearifan lokal yang sudah dijalankan masyarakat Seloto tersebut yaitu budaya Mali (pamali). Pamali (mali) adalah suatu aturan atau norma yang mengikat kehidupan Masyarakat desa. Budaya mali dianggap sebagai kearifan tradisional atau kearifan lokal karena berasal dari warisan leluhur yang telah berlaku secara turun-temurun. Di Desa Seloto, prinsip tradisional tersebut masih berlaku aturan sosial masyarakat yang dapat mengendalikan prilaku manusia dalam berinteraksi dengan alam maupun dengan sesama manusia

Budaya mali atau pamali memiliki aturan yang harus ditaati oleh masyarakat desa. Setiap orang yang melanggarnya selalu mendapat balasan, pelanggaran terhadap mali (pamali) dapat menyababkan terjadinya musibah bukan saja melanda kepada pelanggar tapi juga untuk seluruh penduduk desa. Bentuk-bentuk musibah yang dating dapat bermacam-macam seperti penyakit, kesialan kecil seperti jatuh dari motor, perahu pecah, kehilangan sesuatu, serangan hama tanaman, tanah longsor, angin kencang, banjir bahkan kematian.

Desa Seloto memiliki sumber daya alam yaitu Danau Rawa Taliwang atau dikenal dengan istilah Lebo atau Danau Lebo. Danau Lebo merupakan danau yang unik karena dipenuhi oleh tumbuhan yang mengapung di air, yang bisa bergerak ke mana saja sesuai kemana arah angin bertiup masyarakat Desa Seloto menyebutnya dengan istilah Pruyu. Pruyu-pruyu ini menjadi tempat hidup ikan dan sekaligus menjadi sumber makanan bagi ikan dan juga berfungsi sebagai tempat persembunyian ikan dari para pemburu. Masyarakat Desa Seloto yang menangkap ikan di danau Lebo terikat oleh awiga-wigat aturan yang telah ada sejak dahulu dan menjadi acuan dalam menangkap ikan dan mengelola danau Lebo itu sendiri.

Selain larangan menangkap ikan malam Jum'at, adapula kearifan yang lainnya yaitu Bauanurango, lepasanuodena. Artinya kita hanya menangkap ikan yang besar saja, apabila ada ikan kecil yang sengaja tertangkap maka akan dilepaskan kembali.

Kearifan ini dijalankan oleh masayrakat desa dengan dengan cara menggunakan alat alat tradisional dalam menangkap ikan tidak menggunakan bahan berbahaya seperti potas, bom, strum ikan dan jenis lainnya. Sementara itu ada juga kearifan yang masyarakat menyebutnya Bulan Buntar atau dikenal dengan istilah bulan terang atau bulan purnama, ini sebenarnya merupakan bulan dimana para nelayan tidak menangkap ikan karena mereka percaya pada saat bulan purnama hasil tangkap anakan sangat sedikit, setelah diamati ternyata pada malam bulan purnama cahaya bulan purnama cahaya tersebar di seluruh perairan sehingga ikan pun tidak berpusat di satu tempat, jadi tingkah laku inilah yang mejadi dasar para nelayan menggunakan lampu petromak saat menangkap ikan, karna ketika bulan gelap, maka cahaya sedikit saja terlihat di permukaan air maka ikan dan biota air lainnya akan berkumpul di cahaya tersebut. Hal ini diperkuat oleh pendapat dari Fadli Husain (2011) dalam jurnalnya dengan judul sistem budaya bahari komunitas nelayan lungkak Lombok Timur mengatakan bahwa pada malam hari nelayan akan menggunakan lampu agar menarik ikan-ikan bermunculan di sekitar cahaya lampu. Pada saat bulan purnama, ikan yang muncul berkurang. Hal ini karena terangnya cahaya bulan bercampur dengan cahaya lampu nelayan mampu menembus sampai ke dalam laut yang membuat ikan bergerak ke sana kemari, sehingga sulit untuk ditangkap.

Tabel. Alat-alat Tangkap yang Digunakan Masyarakat 


\begin{tabular}{|c|c|l|}
\hline No & Alat-alat Tangkap & Keterangan \\
\hline 1 & jaring & $\begin{array}{l}\text { Alat tangkap paling sering digunakan } \\
\text { Masayarakat biasanya masyarakat } \\
\text { menggunakan jarring dengan ukuran tertentu }\end{array}$ \\
\hline 2 & Rageng/Tombak & $\begin{array}{l}\text { Alat tangkap yang terlihat mirip seperti } \\
\text { tombak terbuat dari besi dan bambu }\end{array}$ \\
\hline 3 & PistolPanah & $\begin{array}{l}\text { Alat tangkap berupa panah yang dibuat } \\
\text { berbentuk pistol yang terbuat dari kayu besi } \\
\text { dan gabungan dari beberapa pipa plastik }\end{array}$ \\
\hline 4 & Kodong & $\begin{array}{l}\text { Merupakan perangkap yang terbuat dari } \\
\text { bilah bambu dengan cara dianyam }\end{array}$ \\
\hline
\end{tabular}

Dengan menggunakan alat tangakap diatas maka bisa dipastikan ramah lingkungan karena tidak merusak lingkungan, masyarakat juga dilarang menggunakan racun atau sejenisnya dalam menangkap ikan karena akan mencemari danau dan merusak ekosistem danau. Alat tangkap yang paling sering digunakan oleh masyarakat adalah jaring, tetapi menggunakan jaring dengan ukuran ukuran tertentu, kebanyakan masayarakat hanya menggunakan jaring berukuran besar saja sehingga ikan kecil bisa lolos tidak terperangkap dalam jaring.

Kearifan lokal budaya pamali diturunkan dari generasi ke generasi, yaitu dari generasi tua ke generasi muda sejak mereka kecil yang dilakukan dengan lisan melalui cerita-cerita yang disampaikan melalui dengeng. Pendekata nmelalui keluarga menjadi bentuk sosialisasi yang efektif dalam menjaga kearifaan lokal pamali . Kearifan lokal yang berupa budaya pamali berhasil menjaga kelestarian Danau Lebo. Kearifan lokal ini merupakan suatu bentuk aplikasi konservasi sumber daya alam di Danau Lebo. Masyarakat secara sadar melakukan pengelolaan sumber daya alam di Danau Lebo dengan berlandaskan budaya pamali yang telah dilakukan secara turuntemurun. Manfaat yang dapat dirasakan dari keberhasilan masyarakat Desa Seloto dalam menjaga dan melestarikan lingkungan dan sumber daya alam di Danau Lebo yaitu:

1. Menumbuhkan pola hidup taat aturan

2. Kerusakan lingkungan dapat dikendalikan

3. Lestarinya sumber daya alam di Danau Lebo

4. Memiliki potensi kawasan wisata Danau Lebo
5. Tumbuhnya rasa hormat baik sesame manusia maupun dengan alam

Dalam penerapan dan pelestarian kearifan lokal masyarakat memiliki hambatan dan tantangan seperti: jumlah penduduk yang terus meningkat, sehingga kebutuhan akan sumber daya alam begitu besar, adanya teknologi modern dan budaya baru masuk yang dibawa oleh orang pendatang baru, sehingga dikawatirkan orang orang akan terpengaruh dengan teknologi dan budaya baru dan melupakan kearifan lokal yang ada, dan yang paling berpengaruh ialah kemiskinan, dimana kemiskinan juga mempengaruhi orang untuk bertindak memenuhi kebutuhan dasarnya meskipun tindakan tersebut bertentangan dengan norma yang sudah ada ataupun berkaitan dengan kerusakan lingkungan.

Salah satu contoh tantangan tantangan terhadap kelestarian dan keberadaan kearifan lokal yaitu: beberapa orang masyarakat DesaSeloto dalam menangkap ikan sudah mulai menggunakan alat yang namanya strum yang terbuat dari aki mobil, strum ini sangat berbahaya karena dapat membunuh bibit ikan dan juga kalau terjadi kesalahan, strum ini juga dapat membunuh pemakainya.

Dalam menjaga kelestarian sumber daya alam khususnya di Danau Lebo masyarakat Desa Seloto memiliki awiq-awiq atau kearifan lokal, salah satunya yakni budaya mali atau pamali yang diterapkan masyarakat dalam pengelolaan sumber daya alam. Budaya mali itu sendiri memiliki tiga aturan yang harus dipatuhi oleh masyarakat desa diantaranya: larangan menangkap ikan pada hari dan malam Jum'at, larangan menangkap ikan saat bulan purnama dan larangan menangkap ikan-ikan kecil di Danau Lebo.

Selain budaya mali, pemerintah desa juga mengatur pengelolaan dan pelestarian sumber daya alam tersebut dalam peraturan desa tentang pelestarian lingkungan hidup yaitu pada pasal 5 yang berbunyi setiap orang berhak untuk berperan dalam perlindungan dan pengelolaan lingkungan hidup sesuai dengan peraturan perundang-undangan yang berlaku, dan pada pasal 6 berbunyi setiap orang berkewajiban memelihara fungsi lingkungan hidup serta mengendalikan 
pencemaran dan kerusakan lingkungan hidup.

\section{DAFTAR PUSTAKA}

Anwari. 2014. Pengembangan Modul Pembelajaran Biologi Berbasis Kearifan Lokal di Taman Nasional Gunung Merapi untuk SMA Kelas X Materi Keanekaragaman Hayati, Jawa Timur. Skripsi. Yogyakarta: Universitas Negeri Sunan Kalijaga Yogyakarta

Ariska, A. 2015. Pengembangan Modul Biologi Berbasis Gambar Pada Materi Ekosistem Untuk Siswa SMA. Skripsi. Mataram: Institut Keguruan dan Ilmu Pendidikan Mataram.

Aulia dan Dharmawan. 2010. Kearifan Lokal dalam Penegelolaan Sumberdaya Air di Kampung Kuta. Jurnal Fakultas Ekologi Manusia Institut Pertanian Bogor. Vol. 4, No. 3. 25 November 2010.

Burhani, A. 2014. Anlisis Morfometrik Ikan Nila di Kelurahan -SayangSayang Kota Mataram Sebagai Bahan Ajar Mata Kuliah Taksonomi Hewan II. Skripsi. Mataram: Institut Keguruan dan Ilmu Pendidikan Mataram.

Fajriani, U. 2009. Peranan Kearifan Lokal dalam Pendidikan Karakter. Jurnal, Universitas Islam Negeri Syarif Hidayatullah, Jakarta Vol. 1, No. 2

Holilah, M. 2015. Kearifan Ekologis Budaya Lokal Masyarakat Adat Cugugr Sebagai Sumber Belajar IPS. Jurnal Pendidikan Ilmu Sosial. Edisi. Desember 2015. Vol. 24, No. 2

Husain, F.2011. Sistem Budaya Bahari Komunitas Nelayan Lungkak Lombok Timur. Jurnal. Universitas Negeri Semarang Hal. 40-50

MuhA, M, 2012. Pengantar Etika Lingkungan dan Kearifan Lokal. Yogyakarta: Gadjah Mada University Press.

Nasruddin, H.S.B Purwana \& S.D. Kusuma 2011. Kearifan Lokal di Tengah Modernisasi. Jakarta: Kementrian Kebudayaan dan Pariwisata Republik Indonesia.

Prasetyo, E.R.S. Dewi. 2013. Pengembangan Bahan Ajar Biologi Bentuk Cerpen Berorientasi Character Building Berbasis Kearifan Lokal, Jurnal. Jurusan Pendidikan Biologi IKIP PGRI Semarang
Prastowo, 2014. Pengembangan Bahan Ajar Tematik. Jakarta: Kencana

Soegianto, A. 2010. Ilmu Lingkungan Sarana Menuju Masyarakat Berkelanjutan. Surabaya: Airlangga University Press

Soerjani, M. 2009. Pendidikan Lingkungan Sebagai Dasar Kearifan Sikap dan Perilaku Bagi Kelangsungan Kehidupan Menuju Pembangunan Berkelanjutan. Jakarta: Universitas Indonesia (UI-Press)

Suhartini. 2009. Kajian Kearifan Lokal Masyarakat dalam Pengenlolaan Sumber Daya Alam. Yogyakarta: Universitas Negeri Yogyakarta. 15 Mei 2009: 206-218

Sugiyono, 2016. Metode Penelitian Kuantitatif, Kualitatif dan R\&D. Bandung: Alfabeta.

Taprianto, T. 2013. Pengembangan Materi Pembelajaran Menyimak Informasi Bermuatan Kearifan Lokal Pada Siswa SMP, Skripsi. Fakultas Bahasa dan Seni Universitas Negeri Semarang

Tilaar. H.A.R. 1999. Pendidikan Kebudayaan dan Masyarakat Madani Indonesia. Bandung: PT. Remaja Rosdakarya.

Utami,U. 2008. Konservasi Sumber Daya Alam Perspektif Islam dan Sains. Malang: UIN Malang Press

Wangiran. 2011. Pengembangan Model Pendidikan Kearifan Lokal dalam Mendukung visi Pembangunan Daerah Istimewa Yogyakarta 2020, Jurnal Fakultas Teknik Universitas Negeri Yogyakarta. Vol. III, No. 3, Hal. 85-100

Wikantiyoso dan Tutuko. 2009. Kearifan Lokal dalam Perencanaan dan Perancangan Kota. Malang: Malang Group Konservasi Arsitek dan Kota.

Yunus, R. 2014. Nilai Nilai Kearifan Lokal (Local Genius) Sebagai Penguat Karakter Bangsa: Studi Empiris Tentang Huyula, Edisil, cetakan 1 